\title{
HIV-POSITIVE AND HIV-NEGATIVE CONSUMERS ACCEPT AN INSTANT SOY MAIZE POR- RIDGE
}

\section{Susanna C Bouwer}

PhD Food Science and Nutrition

Senior Food Scientist and Nutritionist, North-West University, Potchefstroom

\section{Magdalena JC Bosman}

PhD Food Science

Professor, North-West University, Potchefstroom

Corresponding author: lena.bosman@nwu.ac.za

Keywords: HIV-positive; consumers; acceptability; soy maize porridge

\begin{abstract}
The objective of this study was to assess consumer acceptability, preference and consumption intent of an instant soy maize porridge, compared to an instant plain maize porridge, in order to determine the successful inclusion of the soy maize porridge as a food supplement for HIV subjects in a subsequent nutrition intervention trial, to improve their nutritional status. A 5-point hedonic and food action rating scale was used for this purpose. HIV-positive ( $n=57)$ and HIV-negative ( $n=47$ ) subjects were recruited on a basis of availability and willingness to participate. Long-term acceptability and compliance of HIV-positive consumers $(n=9)$ was assessed after three and five months. Analysis of variance (ANOVA), Tukey's multiple comparison test and T-tests $(p \leq 0.05)$ were performed. Overall, consumers found the soy maize porridge significantly more acceptable, preferred it to, and also intended to consume it more often than the plain maize porridge. There were no significant differences between the HIV-positive and HIV-negative group regarding acceptability, preference and consumption intent. After three and five months, the HIV-positive consumers ( $n=9)$ did not find acceptability of the soy maize porridge significantly different from the first evaluation. It therefore had the potential to be included successfully in the nutrition intervention trial. The current study emphasises the need for sensory evaluation of food products prior to including them in intervention studies, to assess consumers' acceptance of them.
\end{abstract}

\section{OPSOMMING}

Die doel van hierdie studie was om verbruikers se aanvaarding, voorkeur en voorneme van verbruik van ' $n$ kitssojamieliepap, in vergelyking met 'n gewone kitsmieliepap te bepaal, ten einde die suksesvolle insluiting van die kitssojamieliepap as voedselaanvulling vir HIV-proefpersone om hul voedingstatus te verbeter, in ' $n$ daaropvolgende voedingsintervensiestudie te ondersoek. ' $n$ Vyf-punt hedoniese en voedselaksieskattingskaal is vir hierdie doel gebruik. HIV-positiewe ( $n=57$ ) en negatiewe $(n=47)$ proefpersone is op grond van beskikbaarheid en gewilligheid om deel te neem, gewerf. Langtermynaanvaarding en inskiklikheid van HIV-positiewe verbruikers $(n=9)$ is na drie en vyf maande bepaal. Variansie-analise (ANOVA), Tukey se meervoudige vergelykingstoets en T-toetse $(p \leq 0.05)$ is uitgevoer. Verbruikers het oor die algemeen die sojamieliepap betekenisvol meer aanvaarbaar gevind, dit bo die gewone kitsmieliepap verkies, en was ook van voorneme om dit meer dikwels as laasgenoemde te verbuik. Daar was geen betekenisvolle verskille tussen die HIV-positiewe en -negatiewe groep ten opsigte van aanvaarbaarheid, voorkeur en voorneme van verbruik nie. Na drie en vyf maande het die HIV-positiewe verbruikers (n=9) nie die aanvaarbaarheid van die sojamieliepap betekenisvol verskillend van die eerste evaluering gevind nie. Dit het dus die potensiaal gehad om suksesvol in die voedingsintervensiestudie inges/uit te word. Die huidige studie beklemtoon die noodsaaklikheid van sintuiglike evaluering van voedselprodukte voor die insluiting daarvan in intervensiestudies, ten einde verbruikers se aanvaarding daarvan te bepaal. 


\section{INTRODUCTION}

The major global problem of Human Immunodefiency Virus (HIV) infection and Acquired Immune-Deficiency Syndrome (AIDS) has also reached alarming proportions in South Africa. Currently, the Department of Health estimates that approximately 5.54 million South Africans (approximately $10.8 \%$ of the population) have been infected with the virus, while Statistics South Africa estimates that HIVIAIDS accounts for almost $50 \%$ of all South African deaths (The Academy of Science of South Africa (ASSAf), 2007:28-30). The nutrient status of HIV patients seems to be influenced negatively and nutritional deficiencies of especially protein, vitamin $A$ and most of the $B$ vitamins have been associated with deficits in immune function, accelerated disease progression and increased morbidity (Gerrior \& Neff, 2005:8-10; Hsu, Pencharz, Macallan \& Tomkins, 2005:1). It is thus reasonable, in principle, to assume that nutritional interventions administered to people with HIV infections will improve nutritional status and will maintain or enhance defence against infection (McKinley, Goodman-Block, Lesser \& Salbe, 1994:1014), promote recovery from opportunistic infection and improve quality of life and survival. Meta-analysis found that macronutrient supplementation, regardless of type (in the form of a balanced diet or supplements high in protein, fat or carbohydrate), significantly improved total energy and total protein intake while specific amino acid mixtures decreased HIV viral load in HIV-infected participants. Generalisation of the findings should, however, be considered carefully, since all the trials were conducted in the northern hemisphere and evaluated males who were reasonably well nourished (ASSAf, 2007:134).

Scientists are increasingly being charged with the responsibility of clarifying the role that foods play in maintaining and promoting health (Milner, 1998:24). In the light of the above, a nutrition intervention study was planned in which the staple food of the target population of HIV-positive African subjects, namely maize porridge (Vorster, Venter, Kruger, Malan, De Ridder, Wissing, Veldman, Steyn \& Margetts, 1999), would be supplemented with soy in order to improve the nutrient density of the product (Meance, Achour \& Briend, 1999:844; Annan, Plahar, Poll \& Jakobsen, 2005:315), as well as the overall health status of subjects. According to Bosman, Vorster, Drewnowski and Steyn
(1997:98), the fastest way to utilising a new and improved product is to develop a technology that incorporates new products into familiar and acceptable local products without adverse alteration in taste, characteristics or appearance. Previous studies also reported on improved quality of maize meal products or diets when supplemented with soybean (Plahar, Nti \& Annan, 1997:380; Obatolu, Okoruwa \& Iken, 2007:420), as soy is a rich source of high quality plant protein, several vitamins and minerals, as well as phytochemicals (Venter, 1999:33).

However, it seems that the ultimate target of food technology efforts is not just satisfaction of objective consumer needs (nutrition, safety, affordability), but also subjective aspects like sensory properties of food, consumer acceptance and preferences as well as convenience (Karel, 2000:56). Consumer behaviour is becoming increasingly less predictable, more fragmented and less consistent (Imram, 1999:224). Therefore, preceding the human nutrition intervention trial, it was necessary to evaluate consumer acceptance of the soy maize porridge for an indication of the potential consumption of the product to ensure good compliance with the active food ingredients to be tested. Food acceptance is a complex response influenced by psychological, physiological and sensory determinants and can be defined as a positive attitude after the tasting experience (Baker, Wong Hahn \& Robbins, 1994:88). In contrast to preference, acceptance is thus reserved for affective ratings of foods that are actually tasted (Cardello, Schutz, Snow \& Lesher, 2000:202). Consumption measures or level of continued purchase by a specified population are considered to provide a good index of acceptance (Karel, 2000:56). In common practices, researchers who are more interested in the consequences of food acceptance will therefore use behavioural measures, such as consumption, as a primary index (Cardello et al., 2000:202). On the other hand, preference can be defined as an expression of a high degree of liking, a choice of one object over another, or a ranking on a continuous scale from like to dislike (Stone \& Sidel, 2004:248; Moskowitz, Beckley \& Resurreccion, 2006:221). Not only do situational, sensory and hedonic variables play an important role in food acceptance and consumption, but ultimately economic and social factors also need to be addressed (Moskowitz et al., 2006:223). Thus, the concept of food acceptance is a complex one in which preference alone is only one fac- 
tor (Cardello et al., 2000:202).

The objectives of this study were:

- to assess the consumer acceptability of, preference for and intended consumption of an instant soy maize porridge, compared to an instant plain maize porridge;

- $\quad$ to assess whether HIV-positive and HIV-negative subjects differed in evaluating acceptability of, preference for and consumption intent of the two porridge formulas; and

- $\quad$ to assess the acceptability and long-term compliance after regular consumption of the soy maize porridge by HIV-positive subjects.

\section{MATERIALS AND METHODS}

The experimental design for this study is presented in Figure 1.

\section{Subjects}

The target population for this study was black HIV-positive and HIV-negative subjects, recruited on the basis of availability and willingness to take part, as HIV is still a sensitive and confidential matter. It was assumed that all subjects would be capable of assessing the acceptability of maize porridge, as it is the staple food of the target population. The subjects, recruited by the

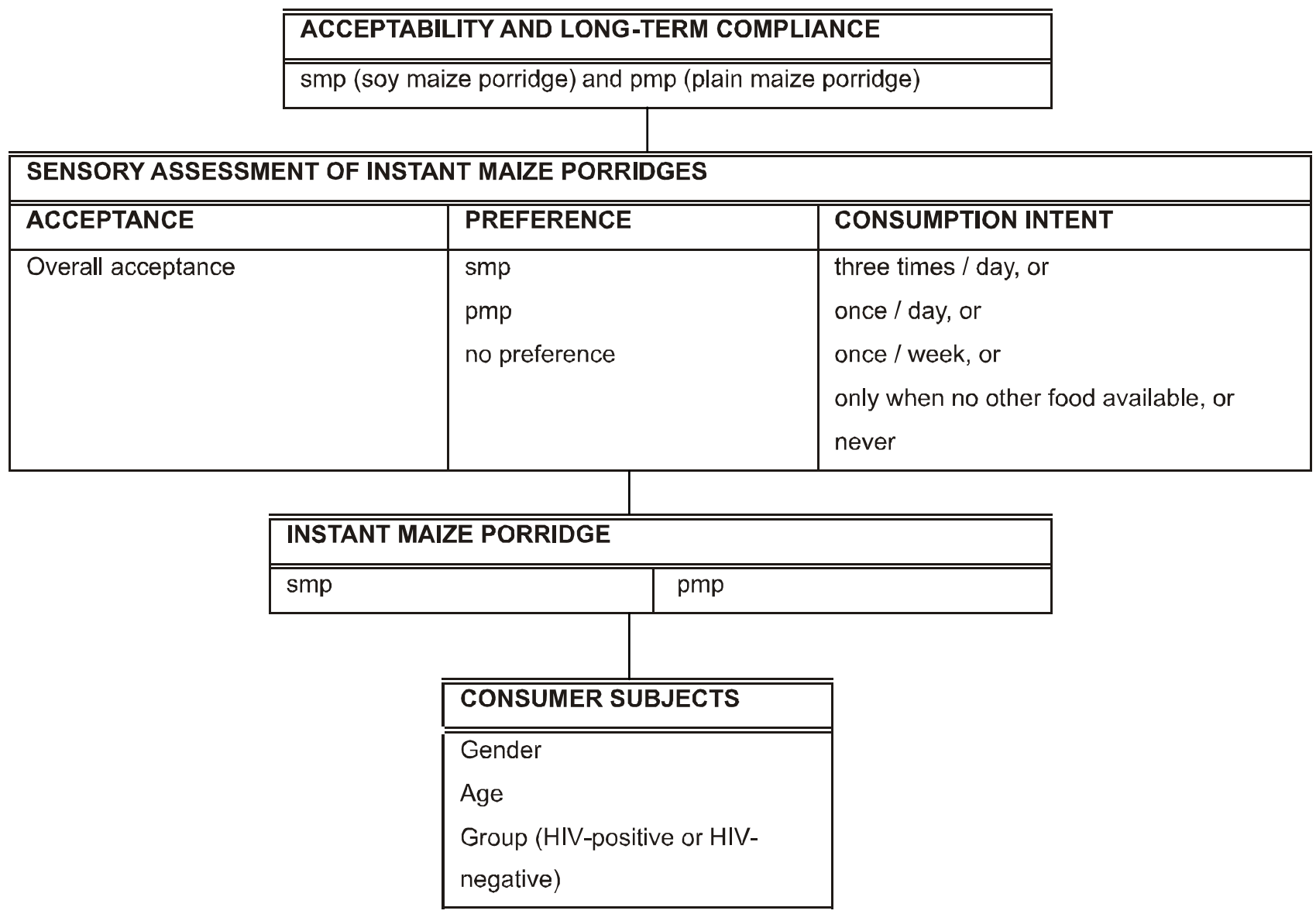

Figure 1: Experimental design of study 
Nutrition Research team of North-West University, Potchefstroom, as part of a clinical study to be executed by the above, were tested anonymously for HIV (Ethical approval, Project 99M04). A total of 104 consumers took part in the study, 57 of whom tested HIVpositive and $47 \mathrm{HIV}$-negative. 58 of the subjects were between 21 and 30 years of age, and 46 were between 31 and 40 years of age, while 72 were female and 32 were male. Consumer tests were conducted in single fold at the taste panel room, North-West University, various other locations in Potchefstroom, as well as in neighbouring community halls.

A second questionnaire was developed to evaluate the acceptability and long-term compliance after regular consumption of the soy maize porridge by some of the 20 HIV-positive subjects that continued with the clinical study. Not all the HIV-positive subjects that initially took part in the consumer study could be recruited for the two follow-up assessments.

\section{Exclusion criteria}

Individuals below the age of 21 years were not allowed to participate, as they do not have any legal right to give consent. The study also excluded pregnant mothers, subjects taking or having taken anti-retroviral drugs and individuals suffering from chronic diseases such as hypertension, tuberculosis and diabetes.

\section{Questionnaire}

The first questionnaire (Bosman et al., 1998:138) was prescreened and pretested and consisted of two sections: one for demographic information and a scoresheet for assessing acceptability of, preference for and consumption intent regarding the two types of porridge. A final question was included to assess consumers' willingness to buy one of the porridge formulas, although more expensive than the other, if it was more healthy and nutritious. Assistance in completing the questionnaire was available during each session.

The second (follow-up) questionnaire assessed acceptability of the soy maize porridge after regular daily consumption, as well as long-term compliance with the product. As HIV can cause decreased appetite and oral lesions (Augustus, 1997:62; Gerrior \& Neff, 2005:7), the researchers were interested in how these changes could possibly have an influence on how much of the porridge subjects regularly consumed, how they preferred to prepare it, as well as how it differed in taste since the first time they had evaluated it.

\section{Sample preparation and presentation}

The instant soy maize porridge was developed by Specialised Protein Products PTY LTD, Potchefstroom. It was developed as an instant food for the convenience of consumers, and is especially beneficial for HIV subjects since it requires less energy for preparation. A plain instant maize porridge, having exactly the same composition but with the exclusion of soy, was used as a control. In order to secure more or less the same texture (consistency) for each sample, $50 \mathrm{ml}$ of dry product was mixed with $50 \mathrm{ml}$ of boiling water for the plain porridge and $75 \mathrm{ml}$ for the soy maize porridge. It was stirred thoroughly with an egg whisk and both samples were served in small, coded plastic containers with lids, placed on a rectangular styrofoam container with a plastic spoon. Coded samples were presented in balanced order to the different subjects to minimise order effects. Evaluation sessions of 10-15 minutes were conducted under controlled conditions, usually around tables in the different community or clinic halls. On arrival subjects were welcomed, seated and informed about the purpose of the consumer test, after which they were presented with one coded sample of each formula and a questionnaire. Subjects were also supplied with water $\left(22^{\circ} \mathrm{C}\right)$ for mouth rinsing before and between samples. Each sample was evaluated once by each subject.

After three and five months, evaluation forms were completed in order to assess acceptability and long-term compliance after regular consumption of the soy maize porridge (completed only by some HIV-positive subjects that were still participating in the clinical study).

\section{Consumer sensory tests}

First questionnaire: In the first sensory test, namely the hedonic rating of the overall acceptability, a 5-point hedonic scale $(1=$ extremely unacceptable, $5=$ extremely acceptable) was used. This 5 -point scale is also balanced with an equal number of positive and negative categories such as the 9-point hedonic scale (Meilgaard, Civille \& Carr, 1991:202) and is often used in consumer studies accommodating different language 
groups (Lawless \& Heymann, 1998:455; Scholtz \& Bosman, 2005:860). A non-forced preference test followed and subjects had to indicate whether they preferred one of the maize porridge samples to the other and, if so, which one. Thirdly, a 5-point food action rating test, with response categories ranging from "never eating it" (score 1), to "eating it 3 times a day" (score 5), was executed to assess consumption intent (Scholtz \& Bosman, 2005:860). According to Cardello et al. (2000:202), consumption is a very good index to measure behavioural measures as a consequence of food acceptance. This test was therefore included since consumers may like a certain food product but may not be willing to consume it frequently or in great quantities (Moskowitz, 1991:188), which could be necessary to ensure compliance. A final question assessed the subjects' willingness to buy a more nutritious maize porridge, even though it might be more expensive (as in the case of the soy maize porridge). Subjects rinsed their palate with water before and between tasting and retasting samples. Experimenters checked the scoresheets for completeness upon completion of the test.

Second questionnaire (completed three and five months after the baseline assessment): Of the original 57 HIVpositive subjects that completed the first questionnaire, 9 of the 20 subjects that still participated in the clinical study executed by the Nutrition Research Group could be recruited again. A 5-point hedonic scale was also used for evaluating overall acceptability after regular consumption of the soy maize porridge. A series of openended and closed questions followed in order to assess subjects' long-term compliance with the porridge.

\section{Statistical analyses}

Demographic data of subjects was analysed using descriptive statistics. Analysis of variance (ANOVA) was applied to the hedonic attribute scores and food action rating scales for each porridge, using Statistica ${ }^{\circledR}$ (StatSoft Inc, 2006). A Tukey's multiple comparison test and T-tests $(p \leq 0.05)$ were performed on the means when significant differences were found in the ANOVA. For the non-parametric variable 'consumption intent' which did not have equal distances between the data categories, significant differences in median within groups were determined using the Wilcoxon matched pairs test, and significant differences between groups were determined using the Mann-Whitney $U$ test (Steyn, Smit, Du Toit \& Strasheim, 1998:16-17). Chi-square tests and multiple comparison of the proportion of preference were performed to determine which of the porridges was preferred.

In the cases where possibilities of a relationship in twoway tables were found (see Tables 2 and 3), this relationship was further examined by descriptive statistics. A natural way to comment on the practical significance of the difference between means is to use the standardised difference between the means, i.e.

$d=\frac{\left|\bar{x}_{1}-\bar{x}_{2}\right|}{S_{\max }}$ where $\left|\bar{x}_{1}-\bar{x}_{2}\right|$ is the difference between $\bar{x}_{1}$ and $\bar{x}_{2}$ without taking the sign into consideration $S_{\max }$ is the maximum of $\mathrm{s}_{1}$ and $\mathrm{s}_{2}$ (Steyn, 2000:3). The following guidelines can be used for the interpretation of the effect size, namely small effect: $d=0.3$; medium effect: $d=0.5$; large effect: $d=0.8$ (Cohen, 1988:25-26). Data with $d \geq 0.8$ was considered as practically significant, since it is the result of a difference having a large effect.

Descriptive methods were used to analyse other openended and closed questions in the second (follow-up) questionnaire.

\section{RESULTS}

\section{Respondents}

The gender and health status distribution amongst the different age groups of the available sample of 104 subjects is given in Table 1.

Of the total sample of consumers, $31 \%$ were male and $69 \%$ were female, while $55 \%$ were HIV-positive compared to the $45 \%$ that were HIV-negative. Although the gender distribution of this consumer sample was uneven due to the fact that subjects were recruited on availability, the age and health status distribution was more even. Of the total number of subjects in the 21-30 year age interval, more were HIV-positive. In contrast, the distribution of HIV-positive and HIV-negative subjects in the 31-40 year age interval was exactly the same. 
Table 1: Demographic data of respondents $(n=104)$

\begin{tabular}{|c|c|c|c|c|}
\hline \multirow[b]{2}{*}{ Age } & \multicolumn{2}{|l|}{ Gender } & \multirow[b]{2}{*}{ Total } & \multirow[b]{2}{*}{$\%$ of total } \\
\hline & Male & Female & & \\
\hline $21-30$ years & 21 & 37 & 58 & 56 \\
\hline $31-40$ years & 11 & 35 & 46 & 44 \\
\hline \multirow[t]{2}{*}{ Total } & 32 & 72 & 104 & 100 \\
\hline & \multicolumn{2}{|l|}{ Health status } & & \\
\hline Age & HIV-positive & HIV-negative & Total & $\%$ of total \\
\hline $21-30$ years & 34 & 24 & 58 & 56 \\
\hline $31-40$ years & 23 & 23 & 46 & 44 \\
\hline Total & 57 & 47 & 104 & 100 \\
\hline
\end{tabular}

\section{Acceptance and intended consumption of porridge variations}

The results of the hedonic and food action ratings for the total statistical population, as well as certain groups within the population, are presented in Table 2 .

According to these results, the soy maize porridge was significantly more acceptable to the total population than the plain maize porridge, although the latter still scored a high mean value. However, the effect of difference on practical significance is small $(d=0.22)$. Consumers also intended to consume the soy maize porridge significantly more often than the plain maize porridge, although the mean value for the latter (3.94) still indicates the intention to eat it at least once a day. This effect of difference on practical significance is also small $(d=0.22)$.

Within the HIV-negative group, neither acceptance nor intended consumption differed significantly for the two formulas. In contrast to this, consumers in the HIVpositive group intended to consume the soy maize porridge significantly more often than the plain maize porridge. This, however, has little effect on practical significance $(d=0.3)$. HIV-positive consumers did not find one of the two formulas more acceptable than the other. In total, there was no significant difference between the HIV-positive and HIV-negative groups regarding acceptability and consumption intent of the two porridge formulas.
Results represented in Table 3 show the effect of gender and age on acceptability and consumption intent. There was no significant difference between male and female consumers regarding acceptability or consumption intent of the two formulas. Although there is no statistical difference, it seems as if consumers in both age groups found the soy maize porridge more acceptable. Consumers in the younger age group (21-30 years) intended to consume the soy maize porridge significantly more often $(4.5 \pm 0.95)$ than the $31-40$ year age group (4.07 \pm 1.27$)$, having almost a medium effect on practical significance $(d=0.4)$. Between the two age groups, no significant difference was found for the plain maize porridge.

According to Figure 2, there is, however, a significant two-way interaction between gender and age for the consumption of soy maize porridge, as the mean consumption intent of men for this formula increased with age (4.1 to 4.5), while it decreased with age in the case of women (4.6 to 3.9).

\section{Preference for porridge variations}

Consumer preference for the different porridge variations is presented in Figure 3. A majority of 66 consumers $(63.4 \%)$ preferred the soy maize porridge to the plain maize porridge, while only 27 (26\%) preferred the plain maize porridge. A total of 11 consumers $(10.6 \%)$ expressed no preference for either of the two porridge formulas. Preference for a porridge formula did not differ 
Table 2: Acceptance and intended consumption of smp and pmp

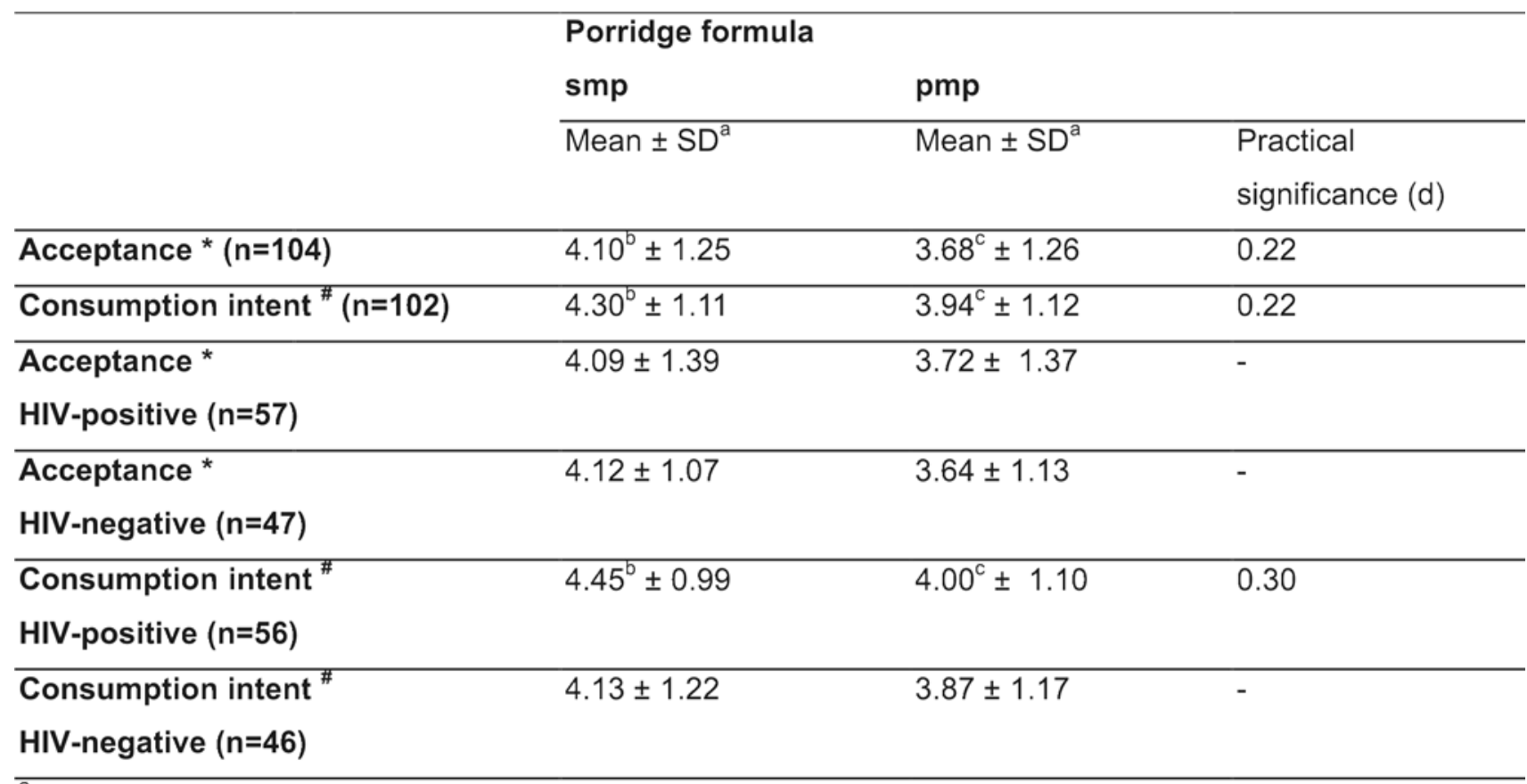

${ }^{\mathrm{a}} \mathrm{SD}=$ standard deviation

${ }^{\mathrm{bc}}$ Means with different superscripts in a row differ significantly statistically $(p<0.05)$

effect/practical significance: $d=0.2$ : small effect; $d=0.5$ : medium effect; $d=0.8$ : large effect (no practical significance indicated when statistical significance is lacking)

* 0-1 = Extremely unacceptable

\# $0-1=$ Will never eat

1-2 $=$ Will eat only when no other food is available

2-3 = Will eat once a week

significantly between the HIV-positive and HIV-negative group (chi square: $0.443 ; p=0.8$ ). When preference was expressed as a total percentage, consumer preference was significantly $(p \leq 0.05)$ in favour of the soy maize porridge.

\section{Willingness to buy the more expensive formula if more nutritious}

According to Forsyth, Anderson and Macintyre (1994:259), the combined burden of poverty, low employment, poor housing and sub-optimal mental and physical health contributes to difficulties in tackling dietary change. Income directly affects access to and availability of a healthy diet and indirectly affects the relationship between food and health (Department of Health, 1996:259). A positive observation from the results of this study, however, is that 90 of the 104 sub-
4-5 = Extremely acceptable

3-4 = Will eat once a day

4-5 = Will eat three times a day

jects $(85.5 \%)$ indicated in the last question that they would consider buying the more expensive porridge formula if it were more healthy and nutritious than the other. On the other hand, only 14 subjects $(13.5 \%)$ had no intention of buying the more expensive of the two formulas. This is probably a good indication of the subjects' willingness to improve their health status.

\section{Acceptability and long-term compliance}

In Table 4 the results are given for acceptability of soy maize porridge after regular consumption, as assessed by HIV-positive consumers.

A total of nine of the consumers who took part in the initial consumer panel, and who were still participating in the clinical study, could be recruited for two followup evaluations. Acceptance of the soy maize porridge did not differ significantly over time. 
Table 3: Effect of gender and age on acceptability and consumption intent

\begin{tabular}{|c|c|c|c|c|c|}
\hline & Gender & & Age & & Practical \\
\hline & Male $(n=32)$ & Female $(n=72)$ & $21-30 y(n=58)$ & $31-40 y(n=46)$ & significance \\
\hline & Mean $\pm S D^{a}$ & Mean $\pm S D^{a}$ & Mean $\pm S D^{a}$ & Mean $\pm S D^{a}$ & for age $(d)$ \\
\hline \multicolumn{6}{|c|}{ Acceptability * } \\
\hline smp & $3.91 \pm 1.30$ & $4.18 \pm 1.23$ & $4.09 \pm 1.23$ & $4.11 \pm 1.27$ & - \\
\hline pmp & $3.81 \pm 0.97$ & $3.63 \pm 1.38$ & $3.57 \pm 1.30$ & $3.83 \pm 1.22$ & - \\
\hline \multicolumn{6}{|c|}{ Consumption ${ }^{\#}$} \\
\hline smp & $4.38 \pm 1.10$ & $4.27 \pm 1.12$ & $4.50^{b} \pm 0.95$ & $4.07^{c} \pm 1.27$ & 0.4 \\
\hline pmp & $4.06 \pm 1.08$ & $3.90 \pm 1.15$ & $3.86 \pm 1.14$ & $4.07 \pm 1.10$ & - \\
\hline
\end{tabular}

${ }^{\mathrm{a}} \mathrm{SD}=$ standard deviation

${ }^{b c}$ Means with different superscripts in a row differ significantly st atistically $(p<0.05)$

smp: soy maize porridge; pmp: plain maize porridge

effect/practical significance: $d=0.2$ : small effect; $d=0.5$ : medium effect; $d=0.8$ : great effect

(no practical significance indicated when statistical significance is lacking)

* 0-1 = Extremely unacceptable

4-5 = Extremely acceptable

\# 0-1 = Will never eat

1-2 $=$ Will eat only when no other food is available

2-3 $=$ Will eat once a week

3-4 = Will eat once a day

4-5 = Will eat three times a day

Plot of Means (unweighted)

2-way interaction

$F(1,94)=4.84 ; p<.0302$

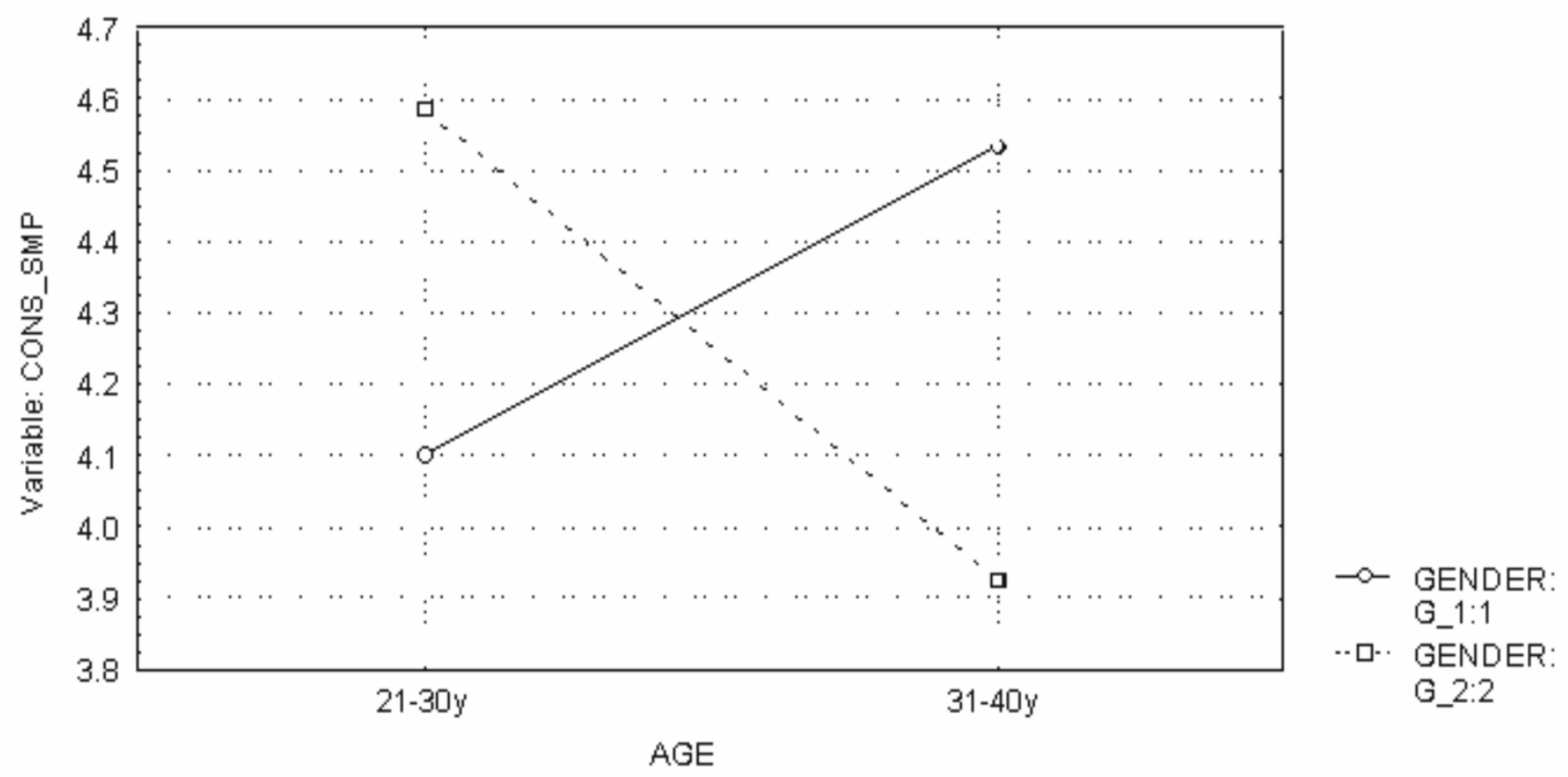

Figure 2: Two-way interaction between age and gender for soy maize porridge (smp) consumption. (-0- G 1:1 Male; -•- G 2:2 Female) 


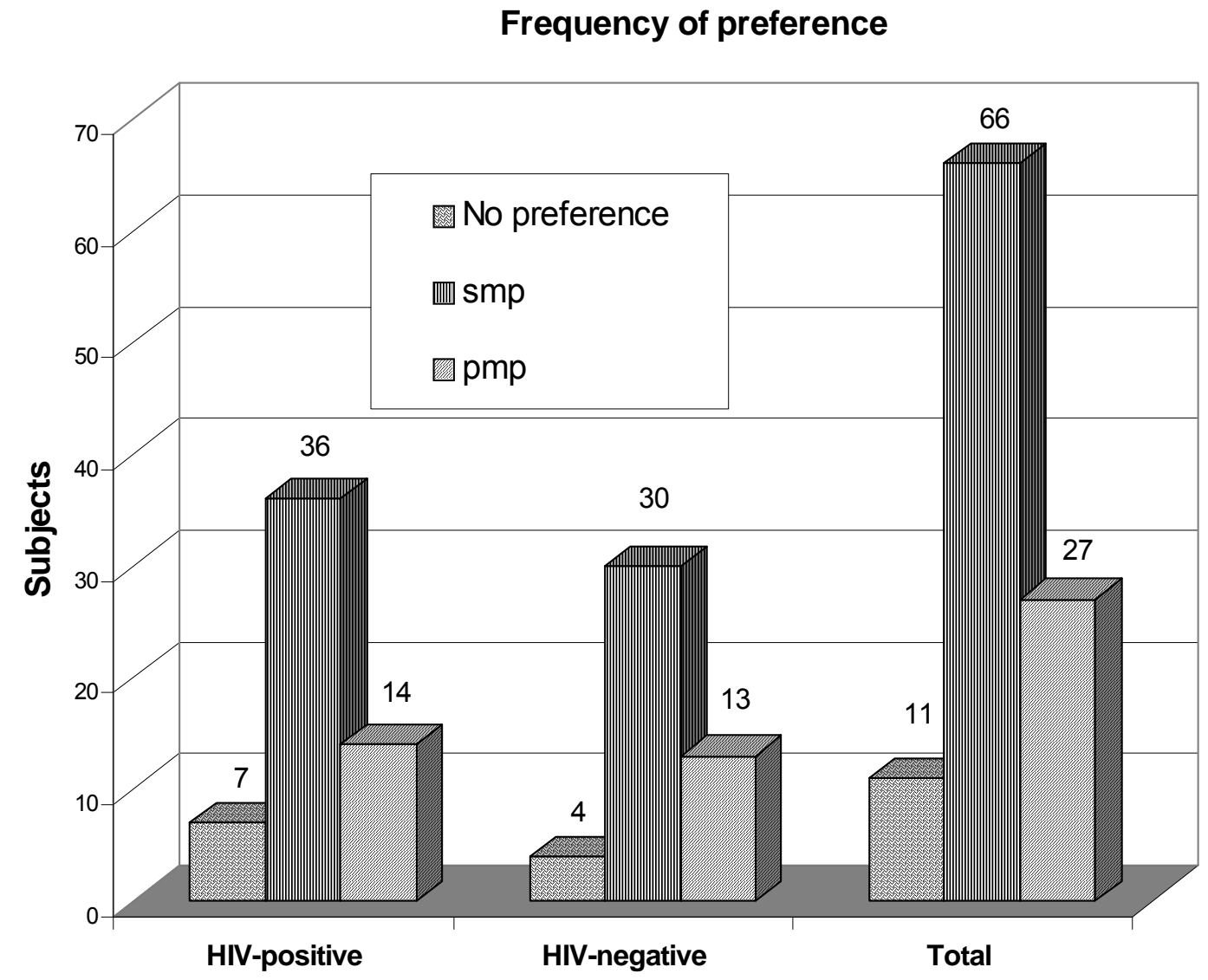

Figure 3: Consumer preference for smp and pmp (Between groups: chi-square value $=0.443 ; p=0.8$ )

Table 4: Acceptance of smp after regular consumption $(n=9)$

\begin{tabular}{ll}
\hline Evaluation & $\begin{array}{l}\text { smp } \\
\text { Mean } \pm \mathrm{SD}^{\mathrm{a}}\end{array}$ \\
\hline Acceptance* 1: Baseline & $3.78 \pm 1.39$ \\
\hline Acceptance $^{*}$ 2: After three months & $3.89 \pm 0.93$ \\
\hline Acceptance* 3: After five months & $4.00 \pm 1.22$ \\
$\mathrm{p}=0.91$ & \\
${ }^{\mathrm{a}} \mathrm{SD}=$ standard deviation & \\
$\mathrm{smp}=$ soy maize porridge & \\
${ }^{*} 0-1$ = Extremely unacceptable 4-5 = Extremely acceptable
\end{tabular}


During the first follow-up evaluation, all the consumers replied that they ate the soy maize porridge given to them as a food supplement daily and that it was acceptable $(3.9 \pm 0.93)$. However, five of the nine consumers only ate half the amount of $300 \mathrm{~g}$ of dry product per day that they were supposed to eat, indicating that their long-term compliance was not very good. Results from the questionnaires indicated only reasons for not eating the porridge at all. Two of the nine consumers mixed their porridge with water and milk, while the others used only hot water because milk was either unavailable, caused nausea or resulted in an overly satiated feeling. Oral lesions can make chewing and swallowing difficult and painful (Augustus, 1997:63) and therefore, as expected, all the consumers preferred the texture of the porridge to be soft (runny). It was reported as easier to consume, not causing as much nausea, and as better tasting or more acceptable in general. Only two of the consumers reported no taste difference compared to the first time they had tasted the porridge, while some of the others found it too sweet, a little too salty or even less sweet than the baseline evaluation. Altered sensations of taste and smell may be due to medication side effects (Augustus, 1997:63).

During the second follow-up evaluation, only one respondent did not eat the soy supplement daily, because it no longer tasted good. Except for this consumer, five others ate the full amount, while the rest ate only half of this amount. The mean value of $4.0 \pm 1.2$ indicated that the product was still very acceptable. The preference for a mixing agent corresponds with the above. During this evaluation, two of the nine consumers preferred the porridge texture to be thick as it was found more acceptable, while the majority still preferred it to be soft, because it was easier to eat and in most cases caused less nausea. Only four respondents reported a taste difference compared to the initial evaluation. Reasons for the taste difference included that it was now either less sweet, less tasty or creamier.

\section{DISCUSSION}

Although these results are positive towards the inclusion of the instant soy maize porridge into the HIV patient's diet, they should not be generalised to a total population, as the respondents participated on the basis of willingness and availability.
Overall, consumers found the soy maize porridge significantly more acceptable, preferred it to and also intended to consume it more often than the plain maize porridge. This is consistent with the finding that other protein formulated or supplemented maize-based products have also been shown to be acceptable (Omueti \& Morton, 1996:5; Obatolu et al., 2007:420).

HIV-positive consumers intended to eat the soy maize porridge significantly more often than the plain maize porridge, a positive result in the light of the recommendation of including or increasing soy in the HIV patient's diet to prevent protein-calorie malnutrition (Augustus, 1997:63) often associated with HIV patients (Gerrior \& Neff, 2005:8). However, they did not find one of the two porridge formulas statistically more acceptable, nor preferred one to the other. No statistical differences were found amongst HIV-negative consumers regarding acceptability of, preference for or intended consumption of the two porridge formulas. In total, there were no significant differences between the HIV-positive and HIVnegative groups regarding acceptability of, preference for and consumption intent of the two porridge formulas.

Younger consumers (21-30 years) intended to eat the soy maize porridge significantly more often than consumers in the older age group (31-40 years). The mean consumption intent of men for this formula also increased with age, while it decreased in the case of women.

Results indicate that, three and five months after the initial acceptability test, the nine HIV-positive consumers that could still be recruited from the clinical trial did not find significant differences in acceptability of the soy maize porridge. Although it was still very acceptable, almost half of these consumers managed to eat the full amount of soy maize porridge given to them daily, while the others ate half of the amount given. Long-term compliance was thus not very good, but it could probably also be attributed to decreased appetite from pain, fatigue or emotional stress (Augustus, 1997:63; Gerrior \& Neff, 2005:7). Compliance of HIV subjects to any given food may possibly decrease as a result of several clinical manifestations. 


\section{APPLICATIONS}

This study emphasises the need for sensory evaluation to be done on food products prior to including them in clinical evaluation studies, to assess consumers' acceptability of them. According to results obtained from consumer studies, adaptations can be made to the product, if necessary, to ensure better acceptability and compliance during clinical trials.

\section{ACKNOWLEDGEMENTS}

The authors wish to thank Specialised Protein Products PTY LTD, Potchefstroom, for providing the instant soy and plain maize porridge used in this study, Prof CS Venter and $\mathrm{Sr} C$ Lessing for recruiting the HIV-positive and HIV-negative subjects, final-year Food Science students for their technical assistance and the NorthWest University, Potchefstroom, for financial support.

\section{REFERENCES}

ACADEMY OF SCIENCE OF SOUTH AFRICA (ASSAf) 2007: HIVI AIDS, TB and nutrition.

ANNAN, NT; PLAHAR, WL; POLL, L \& JAKOBSEN, M 2005: Effect of soybean fortification on Ghanaian fermented maize dough aroma. International Journal of Food Science and Nutrition, 56(5):315-326.

AUGUSTUS, LJ 1997: Nutritional care for patients with HIV. American Journal of Nutrition, 97(10):62-65.

BAKER, RC; WONG HAHN, P \& ROBBINS, KR 1994: Fundamentals of new food product development; $2^{\text {nd }}$ edition. Amsterdam: Elsevier. BOSMAN, MJC; VORSTER, HH; DREWNOWSKI, A\& STEYN, HS 1997: Consumer acceptance of high-fibre muffins containing Simplesse ${ }^{\circledR}$. Journal of Dietetics and Home Economics, 25(2):90-99.

BOSMAN, MJC, VORSTER, HH \& STEYN, HS. 1998. The effect of storage on the characteristics of high-fibre muffins with different levels of a protein-based fat substitute. Journal of Family Ecology and Consumer Sciences, 26(2):131-144.

CARDELLO, AV; SCHUTZ, H; SNOW, C \& LESHER, L 2000: Predictors of food acceptance, consumption and satisfaction in specific eating situations. Food Quality and Preference, 11(3):201-216. COHEN, J 1988: Statistical power analysis for behavioural sciences; $2^{\text {nd }}$ edition. Hillsdale, New Jersey: Erlbaum.

DEPARTMENT OF HEALTH 1996: Low income project team for the nutrition task force. Low income, food, nutrition and health. London: Department of Health.
FORSYTH, A; ANDERSON, AS \& MACINTYRE, S 1994: Diets for disease - Urban food choices. Appetite, 22(3):259-274.

GERRIOR, JL \& NEFF, LM 2005: Nutrition assessment in HIV infection. Nutrition in Clinical Care, 8(1):6-15.

HSU, JWC; PENCHARZ, PB; MACALLAN, D \& TOMKINS, A 2005: Macronutrients and HIVIAIDS: A review of current evidence. Consultation on Nutrition and HIVIAIDS in Africa: Evidence, lessons and recommendations for action. Durban, South Africa 10-13 April 2005. World Health Organization, Department of Nutrition for Health and Development.

IMRAM, N 1999: The role of visual cues in consumer perception and acceptance of a food product. Nutrition and Food Science, 99(5):224-228.

KAREL, M 2000: Tasks of food technology in the $21^{\text {st }}$ century. Food Technology, 54(6):56-64.

LAWLESS, HT \& HEYMANN, H 1998: Sensory evaluation of food - Principles and practices. New York: Chapman \& Hall.

MCKINLEY, MJ; GOODMAN-BLOCK, J; LESSER, ML \& SALBE, AD 1994: Improved body weight status as a result of nutrition intervention in adult, HIV-positive outpatients. Journal of the American Dietetic Association, 94(9):1014-1017.

MEANCE, S; ACHOUR, L \& BRIEND, A 1999: Comparison of starch digestibility of a blend food prepared with and without extrusion cooking. European Journal of Clinical Nutrition, 53(11):844848.

MEILGAARD, M; CIVILLE, GV \& CARR, BT 1991: Sensory evaluation techniques; $2^{\text {nd }}$ edition. Boca Raton: CRC Press.

MILNER, JA 1998: Do "functional foods" offer opportunities to optimize nutrition and health? Food Technology, 52(11):24.

MOSKOWITZ, HR 1991: Optimizing consumer product acceptance and perceived sensory quality. (In: Graf, E \& Saguy, IS ed. Food product development: From concept to the marketplace. New York: Van Nostrand Reinhold, pp 157-188).

MOSKOWITZ, HR; BECKLEY, JH \& RESURRECCION, AVA 2006: Sensory and consumer research in food product design and development. Oxford: Blackwell Publishing.

OBATOLU, VA; OKORUWA, A \& IKEN, JE 2007: Improvement of home-made maize tortilla with soybean. International Journal of Food Science and Technology, 42(4):420-426.

OMUETI, O \& MORTON, ID 1996: Development by extrusion of soybari snack sticks: A nutritionally improved soya-maize product based on Nigerian snack (kokoro). International Journal of Food Science and Nutrition, 47(1):5-13.

PLAHAR, WA; NTI, CA \& ANNAN, NT 1997: Effect of soy-fortification method on the fermentation characteristics and nutritional quality of fermented maize meal. Plant Foods for Human Nutrition, 51(4):365-380.

SCHOLTZ, SC \& BOSMAN, MJC 2005: Consumer acceptance of 
high-fibre muffins and rusks baked with red palm olein. International Journal of Food Science and Technology, 40:857866.

STATSOFT, INC. 2006: STATISTICA (data analysis software system), version 7.1. www.statsoft.com.

STEYN, AGW; SMIT, CF, DU TOIT, SHC \& STRASHEIM, C 1998: Modern statistics in practice. Pretoria: Van Schaik.

STEYN, HS (Jr) 2000: Practical significance of the difference in means. Journal of Industrial Psychology, 26(3):1-3.

STONE, H \& SIDEL, JL 2004: Sensory evaluation practices; $3^{\text {rd }}$ edition. San Francisco: Elsevier Academic Press.

VENTER, CS 1999: Health benefits of soy beans and soy products: A review. Journal of Family Ecology and Consumer Sciences, 27(1):24-33.

VORSTER, HH; VENTER, CS; KRUGER, HS; MALAN, NT; DE RIDDER, H; WISSING, MP; VELDMAN, FJ; STEYN, HS \& MARGETTS, BM 1999: The impact of urbanisation on the health and nutritional status of Africans in the Northwest Province of South Africa: The THUSA study. Presentation at the Health for All in the New Millennium Congress organised by the Australian Centre for International and Tropical Health and Nutrition. Brisbane; 1999: 30 June to 2 July. 